\title{
PLASMA PROTEIN SYNTHESIS IN THE HUMAN FETUS AND PLACENTA ${ }^{1}$
}

\author{
By JOSEPH DANCIS, ${ }^{2}$ NANCY BRAVERMAN, AND JOHN LIND \\ (From the Department of Pediatrics and of Obstetrics and Gynecology, New York University, \\ Bellevue Medical Center, New York, N. Y.; the Wenner-Gren Cardiovascular Re- \\ search Laboratory, and the Department of Pharmacology, Royal Veterinary \\ College, Stockholm, Sweden)
}

(Submitted for publication August 16, 1956; accepted November 16, 1956)

Electrophoretic studies of human fetal plasma have demonstrated a protein pattern in which all major fractions are present (1). The site of origin of these plasma proteins is not known. Presumably they may be synthesized by the mother and merely circulate in the fetus as the result of placental transfer, or they may be synthesized by the placenta or the fetus.

The gamma globulin level is high at birth and falls during the first weeks of life (2). This led to the assumption that the gamma globulin found at birth is derived from the mother by transfer through the placenta, and that the newborn infant does not synthesize it. Because gamma globulin levels (2) and antibody levels (3) are often higher in cord blood than in maternal blood there has been speculation that the placenta may be the site of synthesis. The problem of plasma protein synthesis in the placenta has been approached by comparing levels of the various fractions in blood from the umbilical artery and vein and from the mother (4). It was concluded that the placenta synthesizes albumin.

The present experiments were designed to investigate the synthesis of plasma protein by placenta and fetal liver. Term placenta was obtained at normal deliveries. Liver and placental tissues were also taken from three fetuses of 3 to 4 months gestation (Table I). For purposes of comparison fetal heart was similarly investigated. The fetuses were delivered surgically for psychiatric and social indications and were presumably normal. Tissue slices were incubated with glycine-2-

1 This investigation was supported by a research grant from the Association for the Aid to Crippled Children and by Public Health Service Research Grant No. 4024, National Institutes of Health.

2 John and Mary R. Markle Scholar in Medical Science. A large part of the work was done while Dr. Dancis was a Lowell Palmer Senior Research Fellow.
$\mathrm{C}_{14}$, and the incorporation of radioactivity into plasma proteins was studied. The proteins were isolated and identified electrophoretically and by immunological techniques.

\section{PROCEDURE}

\section{Incubation}

Tissues were procured immediately after delivery and dropped into chilled isotonic saline. Slices about $0.5 \mathrm{~mm}$. thick were prepared with a Stadie-Riggs slicer. One gram of tissue was added to $2.5 \mathrm{ml}$. of Krebs-Ringerbicarbonate buffer (5) in a 25- $\mathrm{ml}$. flask to which had been added 5 micrograms of Aureomycin and about one million counts per minute of glycine-2- $\mathrm{C}_{14}$ (Tracerlab). Radioactivity was determined as described below. The slices were incubated with constant shaking for 18 hours in a water bath at $37^{\circ} \mathrm{C}$.

\section{Electrophoresis}

At the end of incubation, the tissue slices were centrifuged down and discarded. Incubation media from each type of tissue were pooled and dialyzed against three changes of isotonic saline during 24 hours at $5^{\circ} \mathrm{C}$. The bag contents were lyophilized and redissolved in $1 \mathrm{ml}$. isotonic saline to reduce to volumes suitable for electrophoresis. The samples were dialyzed for three hours against veronal buffer, $\mathrm{pH} 8.6$, and then separated by starch electrophoresis and the protein pattern developed as described by Kunkel and Slater (6). One $\mathrm{ml}$. of human plasma was run in parallel on the same block to serve as marker for the plasma protein fractions.

To determine the radioactivity curve, the protein was precipitated from an aliquot of each eluted fraction by the addition of equal volumes of 10 per cent trichloracetic acid (TCA). The precipitate was washed with 5 per cent TCA and extracted with ether to remove the TCA. The precipitate was redissolved in $0.05 \mathrm{~N} \mathrm{NaOH}$, transferred to a planchette, and the radioactivity determined.

\section{Immunological identification of radioactive proteins}

Liver. Carrier precipitates were made in eluates from the starch electrophoresis by adding various plasma fractions and their specific antisera prepared in rabbits. Fractions 5 to 12 (Figure 1), representing the alpha and beta globulins, were pooled, divided into five aliquots, and 
TABLE I

Data on fetuses

\begin{tabular}{rccc}
\hline \hline Fetus & $\begin{array}{c}\text { Weight } \\
\text { (grams) }\end{array}$ & $\begin{array}{c}\text { Gestation* } \\
\text { in days } \\
\text { (history) }\end{array}$ & $\begin{array}{c}\text { Gestation† } \\
\text { in days } \\
\text { (from weight) }\end{array}$ \\
\hline I & 150 & 130 & 120 \\
II & 140 & 195 & 120 \\
III & 240 & 130 & 130 \\
\hline
\end{tabular}

* Calculated from menstrual history. (18)

$\dagger$ Estimated from weight according to graph by Widdas

a specific precipitate of about $2 \mathrm{mg}$. was made in each aliquot. A preliminary titration was done in a small sample of each aliquot, so that appropriate amounts of antigen and antibody were added to produce the precipitate at or near the equivalence point. Precipitates were prepared with the following fractions: human albumin, guinea pig albumin, human beta globulin, beta lipoprotein, and metal-combining globulin. Similar precipitates were prepared in the albumin fraction (17 and 18, Figure 1). All of the specific precipitates were made in aliquots of the eluates containing approximately the same amount of radioactivity. This permits comparison of the amount of radioactivity incorporated in each specific precipitate.

The fibrinogen was located in fractions 12 to 14 by adding thrombin to the concurrently separated human plasma. A precipitate was then formed in fractions 12 to 14 of the incubating medium by adding carrier fibrinogen and the specific antiserum. A similar control precipitate was made in fractions 16 to 18 .

The precipitates were washed with saline, dissolved in concentrated ammonium hydroxide, and transferred to planchettes for determination of radioactivity.

Heart. Because of insufficient material, only electrophoretic separation could be done in the first experiment. In the second experiment, a preliminary separation was performed by dialysis against $1.75 \mathrm{M}$ ammonium sulfate (7). The precipitate, containing all the gamma globulin and a fraction of the other globulins, but little albumin, was redissolved in saline. Immunological precipitates were made in the "albumin" fraction (supernatant) and the "globulin" fraction.

Placenta. After electrophoretic separation, it was demonstrated that the radioactive proteins were distributed in the alpha and beta globulin fractions. These fractions were separated (Figure 3, fractions 5 to 9 and 10 to 14 , respectively), and specific precipitates were made in each fraction.

In earlier experiments with term placentas the technique described by Keston and Katchen was used (8). After incubation the tissues were homogenized and the mixture centrifuged. The supernatant was dialyzed against saline and specific precipitates were made in aliquots of the supernatant without preliminary electrophoresis. To provide an estimate of non-specific adsorption by the protein precipitates, specific precipitates were made

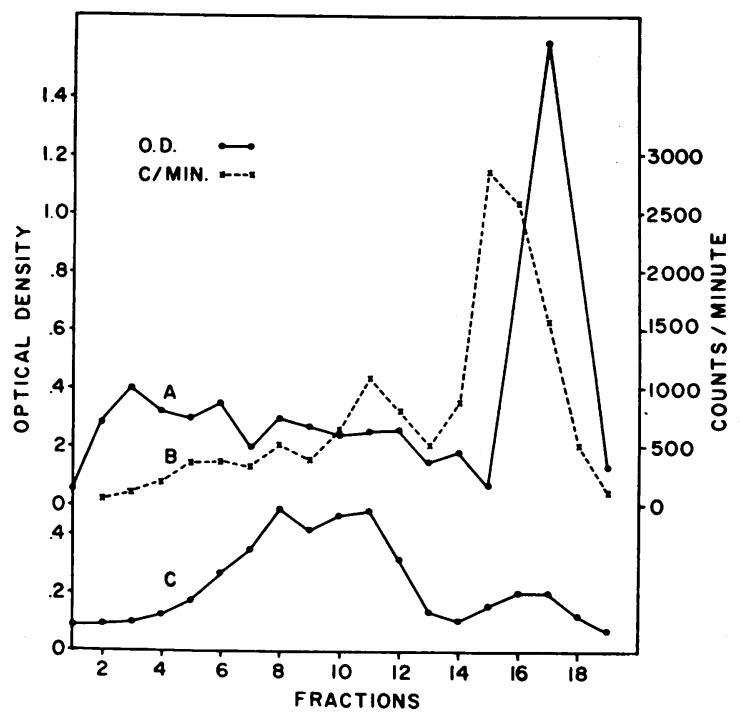

Fig. 1. Synthesis of Proteins by Fetal Liver

A: Electrophoretic pattern of human plasma proteins.

B: Total radioactivity of proteins in the incubating medium. Note similarity to A.

C: Pattern of proteins in incubation medium.

with physically similar but heterologous proteins (ovalbumin, guinea pig albumin, and bovine gamma globulin).

\section{Preparation of specific antisera}

Antisera were prepared in rabbits by the injection of plasma protein fractions with Freund's adjuvant (9). Most of the antisera were prepared by injecting interdigitally 3 to $5 \mathrm{mg}$. of antigen emulsified in $0.5 \mathrm{ml}$. Falba, $1 \mathrm{ml}$. Bayol $\mathrm{F}$ and $1 \mathrm{mg}$. of killed tubercle bacilli. Some of the antisera prepared early in the study required $50 \mathrm{mg}$. of antigen in $4 \mathrm{ml}$. of adjuvant, and the injections were intramuscular.

The human gamma globulin and fibrinogen were obtained from the Department of Biophysical Chemistry, Harvard University. The gamma globulin was electrophoretically pure. The antiserum to fibrinogen was purified by absorption with human serum.

The antisera against beta lipoprotein and metal-combining globulin were generously supplied by Dr. Leonhard Korngold of the Sloan-Kettering Institute for Cancer Research. The preparation of the former and the tests for specificity have been described (10). The latter was prepared by injection of the crystalline antigen and absorption of the antiserum with human gamma globulin and albumin.

The human albumin was supplied by Dr. T. W. Green of Cutter Laboratories, Berkeley, California. It was stated to be 98 per cent electrophoretically pure with the major contaminant alpha globulins. Bovine gamma globulin was obtained from Armour and ovalbumin from Dr. Bernard Katchen.

The beta globulins were prepared by starch electro- 
phoresis of human plasma. Antisera were prepared against alpha and beta globulin fractions individually but were found to be immunologically indistinguishable by the techniques used in this study. They were then used interchangeably. The guinea pig albumin and antiserum were prepared in similar fashion.

\section{Determination of radioactivity}

The protein precipitates were transferred in solution to aluminum planchettes covered with filter paper to produce even distribution, and dried under an infra-red lamp. Radioactivity was determined in a D-46A Nuclear Flow Gas Counter, and the counts were corrected to infinite thinness.

\section{RESULTS}

The electrophoretic pattern of normal plasma proteins (Figure $1 \mathrm{~A}$ ) is paralleled strikingly by the total radioactivity of the proteins in the medium used for the incubation of liver slices (Figure $1 \mathrm{~B}$ ), except that there is no incorporation of radioactivity into proteins with gamma globulin mobility. The electrophoretic pattern of the proteins in the incubation medium (Figure $1 \mathrm{C}$ ), probably representing primarily liver proteins, is quite dissimilar.

Carrier precipitates were made by adding various plasma proteins and their specific antisera to fractions of the electrophoretically separated proteins, as previously described. The results are pre-

TABLE II

Incorporation of radioactivity into proteins by fetal liver (counts per minute) *

\begin{tabular}{|c|c|c|c|c|}
\hline \multirow[b]{2}{*}{ Precipitates } & \multicolumn{2}{|c|}{ Experiment II } & \multicolumn{2}{|c|}{ Experiment III } \\
\hline & $\begin{array}{l}\text { Globulin } \\
\text { fraction }\end{array}$ & $\begin{array}{l}\text { Albumin } \\
\text { fraction }\end{array}$ & $\begin{array}{l}\text { Globulin } \\
\text { fraction }\end{array}$ & $\begin{array}{l}\text { Albumin } \\
\text { fraction }\end{array}$ \\
\hline \multirow[t]{2}{*}{$\begin{array}{l}\text { Total protein } \dagger \\
\text { Albumin (human) } \\
\text { Beta globulin } \\
\text { Metal-combining } \\
\text { Lipoprotein } \\
\text { Gamma globulin } \\
\text { Albumin } \\
\text { (guinea pig) }\end{array}$} & $\begin{array}{r}1594 \\
95 \\
670 \\
171 \\
239 \\
688 \\
58\end{array}$ & $\begin{array}{r}1854 \\
1130 \\
44 \\
10 \\
32 \\
566 \\
26\end{array}$ & $\begin{array}{r}1210 \\
51 \\
598 \\
148 \\
279 \\
560 \\
27\end{array}$ & $\begin{array}{r}915 \\
980 \\
13 \\
2 \\
18 \\
169 \\
50\end{array}$ \\
\hline & $\begin{array}{l}\text { Fibrin- } \\
\text { ogen } \\
\text { fraction }\end{array}$ & $\begin{array}{c}\text { Fibrin- } \\
\text { ogen } \\
\text { control }\end{array}$ & $\begin{array}{l}\text { Fibrin- } \\
\text { ogen } \\
\text { fraction }\end{array}$ & $\begin{array}{c}\text { Fibrin- } \\
\text { ogen } \\
\text { control }\end{array}$ \\
\hline $\begin{array}{l}\text { Total protein } \dagger \\
\text { Fibrinogen }\end{array}$ & $\begin{array}{l}574 \\
186\end{array}$ & $\begin{array}{r}890 \\
78\end{array}$ & $\begin{array}{l}474 \\
201\end{array}$ & $\begin{array}{l}572 \\
105\end{array}$ \\
\hline
\end{tabular}

* Carrier precipitates were formed by adding the protein and its specific antiserum to appropriate electrophoretic fractions (e.g., albumin precipitate in albumin fraction) and, as a control, in inappropriate fractions (e.g., albumin in globulin fraction). Guinea pig albumin precipitates are further controls.

† TCA precipitable radioactivity. sented in Table II. It is evident that a significant amount of radioactivity is carried down by a specific precipitate prepared in the appropriate fraction (e.g., the human albumin precipitate in the albumin fraction), and that it is considerably less in the inappropriate portions of the curve (e.g., the albumin precipitate in the globulin fraction). Precipitates prepared with guinea pig albumin and its specific antiserum, to give an index of nonspecific adsorption, also contain much less radioactivity. The gamma globulin precipitates seemed to give non-specific results. This suspicion was verified by demonstrating extensive cross-reaction between human albumin and our gamma globulin antiserum. The gamma globulin precipitates also incorporated as much radioactivity as the beta globulin precipitates even though the radioactive proteins had an electrophoretic mobility corresponding to the latter.

The results of the experiments with fetal heart are presented in Figure 2 and Table III. The electrophoretic pattern of the radioactive proteins in the incubation medium (Figure $2 \mathrm{~B}$ ) resembles more closely that of the presumed tissue proteins (C) than the plasma proteins (A). The amount of radioactivity incorporated is much less than in the liver experiment (note the difference in scale in Figures 1 and 2).

Unfortunately there was insufficient material after electrophoretic separation to permit immunological identification. Accordingly, in a second experiment, preliminary separation was done with ammonium sulfate. There is a significant amount of radioactivity in the beta globulin and albumin precipitates made in the supernatant (Table III). However, the results with guinea pig albumin in-

TABLE III

Incorporation of radioactivity into specific precipitates by fetal heart (counts per minute) *

\begin{tabular}{lrc}
\hline & $\begin{array}{c}\text { Globulin } \\
\text { fraction }\end{array}$ & $\begin{array}{c}\text { Albumin } \\
\text { fraction }\end{array}$ \\
\hline Total protein & 107 & 124 \\
Albumin (human) & 0 & 56 \\
Beta globulin & 10 & 40 \\
Gamma globulin & 8 & 38 \\
Albumin (guinea pig) & & \\
\hline
\end{tabular}

* Incubation medium proteins were separated by ammonium sulfate precipitation into two fractions and specific precipitates made in each fraction. 


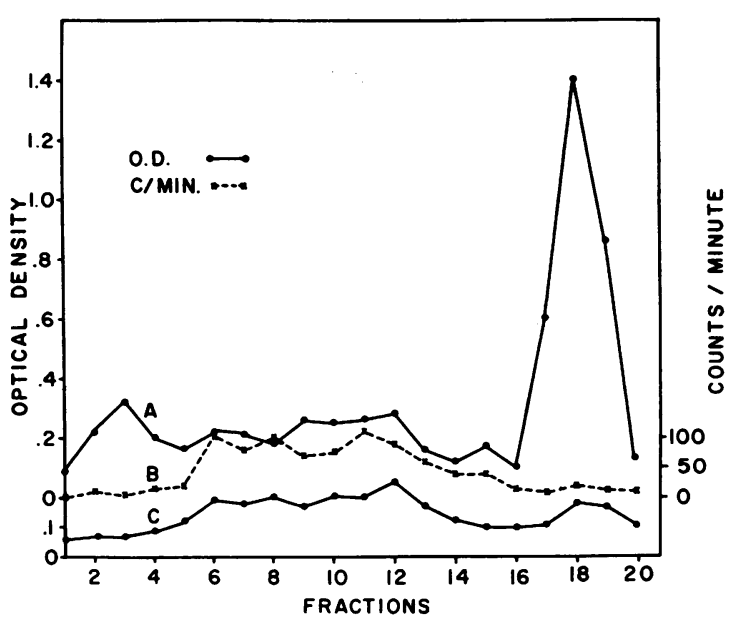

Fig. 2. Synthesis of Proteins by Fetal Heart

A : Electrophoretic pattern of human plasma proteins.

B: Total radioactivity of proteins in the incubating medium.

C: Pattern of proteins in incubation medium. Note similarity of $\mathrm{B}$ and $\mathrm{C}$ in this figure.

dicate that this is probably because of non-specific adsorption.

The results of an experiment with term placenta are given in Figure 3. The total radioactivity of the proteins in the incubating medium (B) parallels the protein pattern (C) more closely than that of the plasma proteins (A). There is no radioactivity in proteins with albumin or gamma globulin mobilities. It is presumed that the albumin peak in $\mathrm{C}$ is derived from blood in the tissue slices since the placenta apparently does not synthesize proteins with this mobility (B).

The results of similar experiments with placentas from 3 to 4-month pregnancies are not reproduced here because there are no important differences. The radioactive proteins moved primarily in the beta and alpha globulin zones. There were no radioactive proteins with albumin mobility, but a small amount overlapped the faster moving gamma globulins. As with term placenta the pattern resembled more closely that of the proteins of the incubating medium than that of plasma proteins.

Carrier precipitates were made by adding plasma proteins and the specific antisera to the alpha and beta globulin fractions (Figure 1, fractions 5 to 9 and 10 to 14 , respectively). In the early placenta, the amount of radioactivity in the precipitates was

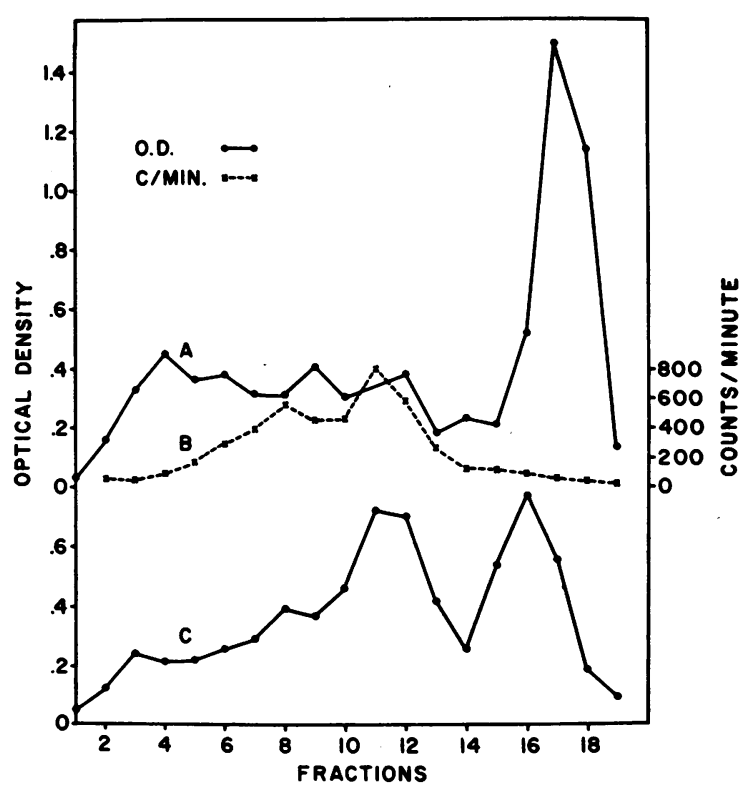

Fig. 3. Synthesis of Proteins by Term Placenta

A : Electrophoretic pattern of human plasma.

B: Total radioactivity of proteins in the incubating medium.

C: Pattern of proteins in incubation medium.

about the same as that obtained with guinea pig albumin, and probably represented non-specific absorption. However, in term placentas there was significantly greater radioactivity in the precipitates prepared with plasma globulins (Table IV).

In earlier experiments using immunological isolation of proteins without preliminary electrophoretic separation (Table $\mathrm{V}$ ), there is more radioactivity in the gamma globulin precipitate than in the control precipitates. In the type of experiment presented in Table V A, the slices were homogenized in the incubating medium and the immunological precipitates made in the supernatant. In Table $\mathrm{V} \mathrm{B}$, the precipitates were made in the incubating medium without preliminary homogenization of the tissue. The reduction in non-specific adsorption is evident.

\section{DISCUSSION}

This investigation was originally undertaken to determine if the placenta could synthesize plasma proteins. The albumin and gamma globulin fractions were first investigated because reports from other workers had suggested that the placenta may synthesize these fractions. The 
TABLE IV

Incorporation of radioactivity into proteins by placenta (counts per minute)

\begin{tabular}{lrrrrr}
\hline \hline & \multicolumn{2}{c}{ Early placenta* } & & \multicolumn{2}{c}{ Late placenta* } \\
\cline { 2 - 3 } \cline { 5 - 6 } \multicolumn{1}{c}{ Protein } & \multicolumn{2}{c}{$\begin{array}{c}\text { Beta } \\
\text { globulins }\end{array}$} & $\begin{array}{c}\text { Alpha } \\
\text { globulins }\end{array}$ & $\begin{array}{c}\text { Beta } \\
\text { globulins }\end{array}$ & $\begin{array}{c}\text { Alpha } \\
\text { globulins }\end{array}$ \\
\hline Total protein & 213 & 260 & & 368 & 443 \\
Albumin (human) & 7 & 7 & & 0 & 25 \\
Alpha globulin & 4 & 21 & & 30 & 105 \\
Beta globulin & 19 & 19 & & 43 & 125 \\
Gamma globulin & & & & 8 & 124 \\
Albumin (egg) & 18 & 14 & & \\
Albumin (guinea pig) & 18 & & & &
\end{tabular}

* Early placenta was from a 3 to 4 months gestation: late placenta was at term. Carrier precipitates were made by adding the plasma protein fraction and its specific antiserum to aliquots after electrophoretic separation. Total protein refers to TCA precipitable radioactivity.

technique described by Keston and Katchen (8) (see Procedure) seemed suitable, and in Table V A are presented the results of a typical experiment with term placenta. The amount of radioactivity incorporated into the gamma globulin precipitate appeared significant; however, the amount of radioactivity in the control precipitates was also appreciable. In a second series of experiments (Table V B), the specific precipitates were made in the incubating medium without preliminary homogenization of the tissue, since it seemed reasonable that the plasma proteins would diffuse out of the cell. This reduced the amount of radioactivity brought down in the control precipitates, verifying the negative results with albumin and making more significant the results with gamma globulin. Cross-reaction between bovine and human gamma globulin (11) probably accounted for the intermediate amount of radioactivity in the former precipitates. These results have been previously presented (12).

The technique of electrophoretic separation followed by immunological precipitation was resorted to in an attempt to better identify the proteins. The data obtained with fetal liver and heart will be discussed first, since they add to the interpretation of the results with placenta.

The experiments with liver give clear cut evidence that the fetus is already capable of synthesizing plasma proteins by 3 to 4 months gestation. The electrophoretic separations indicate that the liver is capable of synthesizing all of the electrophoretically identifiable proteins except gamma globulin. These results conform with those of
TABLE V

Incorporation of radioactivity into specific precipitates by term placenta (counts per minute)

\begin{tabular}{lrr}
\hline \hline & A* & B十 \\
\hline Egg albumin & 75 & 6 \\
Human albumin & 77 & 4 \\
Bovine gamma globulin & 115 & 30 \\
Human gamma globulin & 355 & 72 \\
\hline
\end{tabular}

* A: The tissue slices were homogenized in the incubating medium and carrier precipitates prepared in the supernatant.

† B : Carrier precipitates were made in the incubating medium without preliminary homogenization of tissues.

perfusion experiments with adult rat liver (13) and slice experiments with adult guinea pig liver (14). The immunological studies confirmed the identity of the proteins and gave further information about sub-fractions of the beta globulins.

The gamma globulin precipitates gave puzzling results. The radioactivity carried down in the albumin fraction was probably the result of crossreaction. We later demonstrated extensive crossreaction between our gamma globulin antiserum and albumin. However, the gamma globulin precipitates were just as effective as the $\beta$ globulin precipitates in bringing down radioactivity among proteins with beta and alpha globulin mobility. This was also true in experiments with term placenta, as will be discussed below. It is well known that the plasma globulins are closely related immunologically (15). The question may be raised as to whether immunological differentiation is even less distinct at this early stage of development.

The results with fetal heart are clearly different from those obtained with liver, and conform with what might be expected from an organ that synthesizes proteins for its own use. The radioactive proteins that have diffused into the medium are small in amount and the electrophoretic pattern resembles that of the non-radioactive proteins in the medium, probably representing tissue proteins.

Because of the small amount of tissue available from fetal heart, and the low level of incorporation of radioactivity into proteins, there was insufficient material after electrophoretic separation to permit the preparation of immunological precipitates in the various fractions. In the second experiment, àmmonium sulfate precipitation was employed to separate roughly the proteins: The albumin and beta globulin precipitates made in the supernatant, 
after ammonium sulfate precipitation, had radioactivity. Since this fraction might be expected to contain the albumin and a large proportion of the beta globulins, and since there was also radioactivity in these fractions as determined electrophoretically, this finding might have been considered significant. However, a heterologous precipitate indicated that the radioactivity was incorporated by non-specific adsorption. The proportion of radioactivity brought down with the guinea pig albumin precipitate in this experiment may be contrasted with that in the fetal liver (Tables II and III).

In the experiments with term placenta, electrophoretic identification of the radioactive proteins demonstrated that the placenta did not synthesize proteins with either albumin or gamma globulin mobility (Figure $3 \mathrm{~B}$ ). The proteins moved into the alpha and beta globulin area and appeared to be related immunologically to all three globulin fractions in that each carrier precipitate brought down approximately the same amount of radioactivity (Table IV).

Particular pains were taken with the gamma globulin precipitates because of the paradoxical results with electrophoretic separation. In a series of experiments, different antigens and different antisera were used. In one experiment the gamma globulin antigen was prepared by precipitating diphtheria toxoid with immune human serum, the precipitate being largely composed of the specific anti-diphtheria gamma globulin. The results in all experiments were essentially the same.

It would be of interest to know if the globulins synthesized by the placenta have functional similarities to plasma globulins. Good and Zak have presented an interesting report (16) of a woman with agammaglobulinemia who was immunized repeatedly during pregnancy. Antibodies were detected in the mother in the last months of pregnancy and circumstantial evidence indicated that the placenta might be the source of the antibodies. Since some antibodies have electrophoretic mobilities similar to those of the radioactive proteins in our experiments with placenta (17), we made attempts to demonstrate antibody synthesis using the Keston and Katchen technique with placentas from mothers immunized against tetanus and diphtheria. The attempts were unsuccessful. This does not exclude the possibility that the placenta synthesizes antibodies in amounts too small to be detected by this technique, or that it may synthesize antibodies under abnormal conditions (for example, agammaglobulinemia in the mother).

It is not likely that under normal circumstances the placenta contributes significantly to the plasma proteins of the fetus. The placenta from pregnancies of 3 to 4 months duration does not synthesize any plasma proteins detectable by this technique (Table IV). By this stage of pregnancy, the fetal liver is already actively synthesizing all plasma protein fractions except the gamma globulin. The gamma globulins as identified electrophoretically are probably supplied by the mother.

\section{SUMMARY}

1. Liver slices from human fetuses of 3 to 4 months gestation were incubated with glycine-2$\mathrm{C}_{14}$. The proteins were separated electrophoretically and immunologically, and the incorporation of radioactivity was determined. It was concluded that the liver at this stage of development is already capable of synthesizing plasma proteins, exclusive of gamma globulin.

2. Similar studies were conducted using human fetal heart for purposes of comparison. The differences were striking and conform with the picture of an organ synthesizing proteins for its own use.

3. Experiments with human placenta from pregnancies of 3 to 4 months duration have demonstrated that the placenta will incorporate glycine-2$\mathrm{C}_{14}$ into proteins with alpha and beta globulin mobilities. These proteins are immunologically unrelated to plasma proteins.

4. Similar experiments with term placentas revealed incorporation of radioactivity into proteins with similar electrophoretic mobility. However, these proteins are related immunologically to plasma globulins.

5. At neither stage of pregnancy does the placenta synthesize proteins that are electrophoretically identifiable as albumin or gamma globulin.

6. It is concluded that under normal circumstances the placenta does not contribute significantly to the plasma proteins of the fetus. Beginning early in gestation, the fetal liver is capable of synthesizing all plasma proteins except gamma globulin. The gamma globulin is probably derived from the mother. 


\section{ACKNOWLEDGMENT}

We are indebted to Dr. A. M. Pappenheimer, Jr. of the Department of Immunology and Dr. Milton Levy of the Department of Biochemistry for many helpful discussions. Dr. Bernard Katchen assisted with the preliminary experiments.

\section{REFERENCES}

1. Moore, D. H., DuPan, R. M., and Buxton, C. L., An electrophoretic study of maternal, fetal, and infant sera. Am. J. Obst. \& Gynec., 1949, 57, 312.

2. Orlandini, T. O., Sass-Kortsak, A., and Ebbs, J. H., Serum gamma globulin levels in normal infants. Pediatrics, 1955, 16, 575.

3. Osborn, J. J., Dancis, J., and Rosenberg, B. V., Studies of the immunology of the newborn infant. III. Permeability of the placenta to maternal antibody during fetal life. Pediatrics, 1952, 10, 450.

4. Ewerbeck, H., von, and Levens, H. E., Utber die bildung der Serumeiweisskörper in der Placenta sowie ihren beitrag am Fettstoffwechsel des Feten. Ztschr. f. Kinderh., 1951, 99, 297.

5. Umbreit, W. W., Burris, R. H., and Stauffer, J. F., Manometric Techniques and Tissue Metabolism. Minneapolis, Burgess Publishing Co., 1949.

6. Kunkel, H. G., and Slater, R. J., Zone electrophoresis in a starch supporting medium. Proc. Soc. Exper. Biol. \& Med., 1952, 80, 42.

7. Eisen, H. N., Carsten, M. E., and Belman, S., Studies of hypersensitivity to low molecular weight substances. III. The 2,4-dinitrophenyl group as a determinant in the precipitin reaction. J. Immunol., 1954, 73, 296.

8. Keston, A. S., and Katchen, B., Incorporation of glycine-2-C14 into homologous antibody by rabbit tissue slices. J. Immunol., 1956, 76, 253.
9. Freund, J., and Bonanto, M. V., The effect of paraffin oil, lanolin-like substances and killed tubercle bacilli on immunization with diphtheric toxoid and Bact. typhosum. J. Immunol., 1944, 48, 325.

10. Korngold, L., and Lipari, R., Immunochemical studies of human plasma beta lipoprotein. Science, 1955, 121, 170.

11. Maurer, P. H., The cross reactions between albumins of different species and gamma globulins of different species. J. Immunol., 1954, 72, 119.

12. Dancis, J., Braverman, N., and Katchen, B., The synthesis of serum proteins by human placenta. Am. J. Dis. Child., 1955, 90, 558.

13. Miller, L. L., and Bale, W. F., Synthesis of all plasma protein fractions except gamma globulins by liver. The use of zone electrophoresis and lysine-E-C ${ }^{14}$ to define the plasma proteins synthesized by the isolated perfused liver. J. Exper. Med., 1954, 99, 125.

14. Dancis, J., and Braverman, N., Unpublished data.

15. Cohn, M., Deutsch, H. F., and Wetter, L. R., Biophysical studies of blood plasma proteins. XIII. Analysis of immunological heterogeneity of human gamma globulin fractions. J. Immunol., 1950, 64, 381.

16. Good, R. A., and Zak, S. J., Disturbances in gamma globulin synthesis as "experiments of nature." Pediatrics, 1956, 18, 109.

17. Slater, R. J., The serum gamma-globulins defined by electrophoretic and immunologic analyses. Arch. Biochem. \& Biophys., 1955, 59, 33.

18. Widdas, W. F., Some aspects of foetal and placental physiology. Etudes Néonatales, 1954, III, 165.

Taken from data by Friedenthal, H., Allgemeine und spezielle Physiologie des Menschenwachstums für Anthropologen, Physiologen, Anatomen, und Ärzte dargestellt. Berlin, Springer, 1914. 